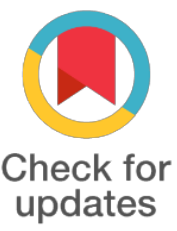

updates

*For correspondence:

yasutomo(@)tokushimau.ac.jp

Competing interests: The authors declare that no competing interests exist.

Received: 2017-04-29

Accepted: 2017-06-12

Published: 2017-09-05

Copyright The Author(s) 2017. This article is published with open access by BioMedPress (BMP).

This article is distributed under the terms of the Creative Commons Attribution License (CC-BY 4.0) which permits any use, distribution, and reproduction in any medium, provided the original author(s) and the source are credited.

\section{Notch-mediated control of memory T cells against cancer cells}

\author{
Koji Yasutomo
}

Department of Immunology and Parasitology, Graduate School of Medicine, Tokushima University

\section{Abstract}

T cells recognize an antigen presented by self-MHC, and the part of initially activated T cells differentiate toward memory $T$ cells. T cells also recognize cancer cells leading to generation of memory $T$ cells against cancer-derived antigens although the activity of $T$ cells are frequently suppressed by various factors. The release from $T$ cell inhibitory factors could allow $T$ cells to respond to cancer cells. However, it remains unclear which molecules are required for long-term survival of memory $T$ cells and generation of memory $T$ cells against cancer cells. Notch functions as a regulator for fate decision, activation and survival of immune cells. We have demonstrated the roles of Notch in mature T cell differentiation and found that Notch signaling is essential for the maintenance of memory CD4 T cells. The inhibition of Notch disturbs the survival of memory CD4 T cells. The effect of Notch on T cell survival depended on glucose uptake through cell surface Glut1 expression. We revealed that Notch is crucial for the long-term survival of memory T cells against cancer cells and suppression of Notch signaling reduced the tumor antigen-specific killing of cancer cells. Those data demonstrate that Notch is pivotal for the maintenance of memory $T$ cells against cancer cells and suggest that activation of Notch signaling might be advantageous to cancer immunotherapy.

Keywords

Funding

References 